\title{
PENGEMBANGAN INDEKS PENGUNGKAPAN DENGAN MAQASHID SHARIAH DALAM MEMUNCULKAN INDIRECT STAKEHOLDER YANG TERLUPAKAN
}

\section{DEVELOPMENT OF DISCLOSURE INDEX BASED ON MAQASHID SHARIA TO APPEAR FORGED STAKEHOLDER INDIRECT}

\author{
Krisno Septyan'1a; Wisnu Julianto ${ }^{2}$ \\ 1aJurusan Akuntansi, Universitas Pembangunan Nasional Veteran Jakarta, Jl. RS \\ Fatmawati, Pd. Labu, Cilandak, Kota Depok, Daerah Khusus Ibukota Jakarta 12450, \\ e-mail: Krisno.septyan@upnvj.ac.id \\ ${ }^{2} J u r u s a n$ Akuntansi, Universitas Pembangunan Nasional Veteran Jakarta, Jl. RS \\ Fatmawati, Pd. Labu, Cilandak, Kota Depok, Daerah Khusus Ibukota Jakarta 12450, \\ e-mail: antoacid@gmail.com
}

\begin{abstract}
This research aims to add of disclosure item based on maqashid shariah (hifzun Nasb Approach). This reseeach used qualitative method with cristism paradigm based on Islamic perspective and spiritualism paradigm. The result shows that Islamic bank in Indonesia has more disclose about direct stakeholder than indirect stakeholder. Even that new stakeholder (family) has a little more on disclosure percentage than others stakeholders. Another finding is transfer welfare policy for another stakeholder which should for this new stakeholder.
\end{abstract}

Keywords: Disclosure, Maqashid Syariah, Indirect Stakeholder

\begin{abstract}
ABSTRAK
Penelitian ini bertujuan untuk memberikan tambahan item pengungkapan berdasarkan maqashid syariah (pendekatan pada hifzun Nasb). Metode yang digunakan adalah kualitatif dengan paradigma kritis berdasarkan pandangan Islam dan paradigma spiritualis. Hasilnya menunjukkan bank umum syariah di Indonesia lebih banyak mengungkapkan kegiatan yang berkaitan dengan direct stakeholder dibandingkan dengan indirect stakeholder. Bahkan stakeholder baru (keluarga) memiliki persentase paling kecil dibanding stakeholder lainnya. Temuan lainnya mengenai kebijakan kesejahteraan terkait dengan stakeholder ini malah menjadi kesejahteraan untuk stakeholder lainnya.
\end{abstract}

Kata Kunci: Pengungkapan, Maqashid Syariah, Indirect Stakeholder

Krisno Septyan. 2018. Pengembangan Indeks Pengungkapan dengan Maqashid Shariah dalam Memunculkan Indirect Stakeholder yang Terlupakan. Jurnal Nisbah 4 (2): 110-121. 


\section{PENDAHULUAN}

Sistem perbankan syariah merupakan sistem yang inovatif dengan memberikan berbagai model pembiayaan sesuai kebutuhan nasabah, sehingga kita dapat membedakan antara sistem perbankan syariah dengan sistem perbankan konvensional. Dibalik keinovatifan sistem perbankan syariah terdapat tujuan penting, yaitu berbagi kesejahteraan kepada seluruh stakeholder. Hal ini diambil dari berbagai macam makna syariah yang dibawakan oleh Yuslam Fauzi sebagai Wakil Ketua IAEI ketika membawakan materi maqashid syariah. Kesimpulan yang diberikan adalah makna syariah berdasarkan ruang lingkupnya antara lain makna syariah secara sempit hanya berorientasi pada fiqih yaitu mencari perbedaan antara sistem syariah dan terlarang, sedangkan makna syariah secara luas memiliki tujuan yang dikenal dengan maqashid syariah yaitu memberi titik akhir pada kesejahteraan.

Dari hal diatas dapat diambil kesimpulan bahwa indikator keberhasilan entitas syariah bukan hanya pada kenaikan laba, aset ataupun dana pihak ketiga entitas yang bersangkutan, tetetapi juga kesejahteraan masyarakat sekitar turut meningkat. Manusia merupakan khalifatullah fil ard yang memiliki amanah untuk mengelola bumi dan berbagi kesejahteraan kepada seluruh stakeholder (Triyuwono, 2012). Tidak hanya stakeholder yang terlibat langsung dalam menghasilkan laba perusahaan (direct stakeholder), tetetapi juga indirect stakeholder seperti alam, masyarakat yang membutuhkan perlu diperhatikan perusahan.

Kesejahteraan merupakan indikator penting untuk menghilangkan keegoisan diri (entitas), walaupun entitas sebuah alat tetapi entitas tidak bebas dari nilai-nilai kehidupan baik nilai positif ataupun nilai negatif karena penggerak alat tersebut adalah manusia yang memiliki hati dan pikiran. Begitu juga dengan akuntansi bukan sebuah hal yang netral (bebas dari nilai), tetetapi akuntansi itu bersifat diskursif, yaitu ketika akuntansi lahir dari dunia kapitalis, maka informasi yang tersaji pun sarat dengan angka untuk tunduk patuh pada kepentingan golongan tertentu. Begitu juga sebaliknya, jika akuntansi lahir dari entitas syariah, maka informasi yang disajikan harus memiliki nilai-nilai akhlak, dimana informasi yang disajikan merefleksikan kegiatan entitas agar harta tidak berputar pada golongan tertentu. Dengan hal tersebut, maka perusahaan mulai peduli kepada kesejahteraan seluruh pihak tidak hanya direct stakeholder.

Banyak dalil yang menekankan untuk berbagi kesejahteraan lingkungan sekitar yaitu kepada alam dan manusia, terlebih untuk pihak-pihak yang membutuhkan. Sehingga ketika membahas syariah dalam konteks yang luas, yang diperhatikan adalah kesejahteraan, bukan mengumpulkan harta sebanyak-banyaknya, karena indikator kebaikan bukan terletak pada banyaknya aset yang dimiliki seperti yang tertuang dalam QS. Al-Fajr: 15-16 dimana manusia terlalu cepat membuat kesimpulan seolah ketika banyak harta menunjukkan bahwa ia sedang dimuliakan oleh Tuhannya, tetapi jika dalam kondisi harta yang sedikit maka mereka berasumsi sedang dihinakan oleh Tuhannya. Dalam QS Al-Mu'minun: 55-56 menunjukkan banyak harta bukan pertanda kebaikan jika orang yang diberi harta namun selalu dalam kemaksiatan kepada Tuhannya (Istidraj). Termasuk larangan kagum atas harta dan anak bagi orang yang beriman karena dunia yang sedang diberikan adalah siksa dari Allah (QS. At-Taubah: 55). Tetapi Allah tidak melarang untuk kaya seperti dalam QS 
At-Taubah: 20 Islam juga menyuruh kaya sebagai salah satu cara berjihad dengan harta yang dimiliki.

Dengan demikian urgen perusahaan adalah bukan hanya fokus pada peningkatan aset, tetapi juga bagaimana untuk mendistribusikan laba dalam rangka berbagi kesejahteraan. Dalam beberapa penelitian menyarankan sisa dari laporan nilai tambah dapat didistribusikan seluruhnya. Triyuwono (2012) juga menyatakan bahwa tujuan akhir akuntansi syariah bukan laba. Laba hanya mediari untuk didistribusikan kembali berupa zakat. Sehingga target perusahaan bukan lagi laba, tetapi zakat. Entitas akan menjalankan fungsinya untuk berbagi kesejahteraan. Jika laba tidak tercapai untuk target zakat yang ditetapkan, setidaknya sudah memiliki pahala atas niat tersebut karena tujuan akuntansi syariah adalah falah yang merupakan salah satu goal entitas syariah beroperasi (Nurhayati dan Wasilah, 2014).

Penelitian lainnya seperti Docekalova (2013) memperhatikan stakeholder lainnya dengan memberikan indikator kinerja perusahaan bukan hanya dilihat dari sisi keuangan saja, tetapi juga sisi sosial dimana penelitiannya memberikan penekanan pada sosial dan lingkungan khususnya pada lingkungan karyawan. Dan banyak penelitian lain yang memberikan gambaran secara subjektif bahwa perusahaan perlu memberikan informasi tidak hanya dilihat dari sisi keuangan (AAOIIFI mengeluarkan indeks pengungkapan wajib dari sisi akuntansi dan keuangan karena berkonsentrasi pada standar laporan keuangan).

Informasi-informasi

lainnya

tertuang dalam indeks yang dikembangkan oleh peneliti terdahulu dengan berbagai sudut pandang, seperti Harahap (2002) membuat pengungkapan Islamic Value di perbankan syariah, Hameed, Wirman,
Alrazi, Nazli, \& Pramono (2003) memiliki Islamicity Disclosure Index, Othman membuat Islamic Social Reporting yang berasal dari Haniffa (2002). Asutay \& Harningtyas (2015) mengembangkan indeks maqashid syariah dengan mengevaluasi kinerja sosial bank syariah. Hingga Septyan (2016) menggabungkan beberapa indeks pengungkapan terdahulu dengan dasar Shariah Enterprise Theory. Dari beberapa indeks pengungkapan yang telah dibuat oleh peneliti terdahulu memiliki kesamaan yaitu agar perusahaan peduli terhadap seluruh stakeholder walaupun penekanan pengungkapan pada stakeholder tertentu berbeda pada setiap peneliti.

Sedangkan dalam penelitian ini mengembangkan indeks pengungkapan yang diambil dari beberapa peneliti terdahulu dengan tambahan dasar maqashid syariah pada tambahan stakeholder yang tidak terlibat langsung dalam kontribusi laba (indirect stakeholder) namun memiliki kaitan erat dengan para stakeholder yang terlibat langsung dalam kontribusi laba perusahaan (direct stakeholder). Stakeholder tersebut adalah keluarga. Menurut Abu Ishaq Ash Shatibi, fokus maqashid syariah dibagi menjadi lima, salah satunya adalah hifdzun nasb (memelihara keturunan).

\section{MATERI DAN METODE}

\section{Shariah Enterprise Theory}

Dalam akuntansi syariah, teori yang paling tepat adalah syariah enterprise theory karena dalam teori tersebut merefleksikan hubungan yang peduli terhadap semua stakeholder bahkan dalam perusahaan pun dikenal stakeholder tertinggi yaitu Tuhan. Sehingga akuntansi dilihat dari paradigma spiritualis akan mengembalikan kesadaran Tuhan sebagai tempat bergantung. Dijabarkan 
dalam Triyuwono (2012) oleh Harahap (1996) bahwa teori tersebut lebih lengkap karena mencakup aspek sosial dan pertanggungjawaban. Lebih ditegaskan oleh Tiryuwono (2012) agar enterprise theory menjadi syariah maka memasukan Tuhan sebagai stakeholder tertinggi.

Sedangkan makna syariah yang berarti aturan. Jika yang dimaksud adalah aturan Islam, maka syariah akan merujuk pada sumber aturan (hukum) yaitu al-Quran dan hadist. Dengan demikian, dapat disimpulkan bahwa entitas syariah adalah entitas yang beroperasi atas dasar al-Quran dan hadits. Dapat dicontohkan seperti bank syariah adalah bank yang bergerak atas dasar Al-Qur'an dan hadist dimana bank syariah tidak menjalankan transaksitransaksi riba karena dalam QS 2: 275 terdapat pelarangan riba. Sehingga bank syariah mencari alternatif lain, yaitu seperti menggunakan akad jual beli, bagi hasil, sewa dan sebagainya. Ada juga bank yang tidak menggunakan nama syariah, tetetapi menggunakan system bagi hasil dan tidak menggunakan bunga, lalu apakah bank ini juga akan dinamakan syariah jika bank tersebut tidak merujuk pada Al-Qur'an dan Hadits. Jawabannya tentu tidak.

\section{Maqashid syariah}

Maqashid syariah terdiri dari dua kata yaitu maqashid dan syariah. Maqashid berasal dari kata qashada yang berarti tujuan, memaksudkan atau menghendaki. Dan kata syariah artinya jalan menuju sumber air dan diartikan juga sebagai sumber kehidupan. Sehingga maqashid syariah adalah tujuan syariah dimana makna syariah secara luas untuk menjadikan segala sesuatunya lebih baik. Sehingga makna syariah secara universal bukan hanya berpatokan pada halal atau haram atau mengemas sesuatu agar menjadi syariah, tetapi lebih mencapai tujuan untuk segala aspek kehidupan menjadi lebih baik.

Dalam makna syariah secara universal, tujuan lebih terarah yaitu untuk segala sesuatunya lebih baik. Jadi tujuan syariah itu sendiri adalah kesejahteraan para stakeholder. Pesan ulama dari Imam Ghazali, Ibnu Taimiyah dan Imam Syatibi adalah Allah menurunkan syariah adalah untuk kemaslahatan (kesejahteraan). Pesan AlQuran dalam QS Al-Fajr ayat 15-20 adalah Allah menyuruh kita untuk berbagi harta, agar orang-orang yang membutuhkan juga merasakan nikmatnya harta kita, sehingga kita terhindar dari cinta dunia. Maka dari itu, syariah memiliki tujuan berbagi kesejahteraan.

Ketika berbicara syariah secara universal, maka membuka diri menjadi hal penting, wawasan luas berdasarkan Al Quran dan Hadist menggambarkan kemajuan berfikir. Bukan menjadi pribadi fanatik dan hanya mencari perbedaan yang syariah dan tidak syariah. Lain halnya ketika kita berbicara akidah. Karena akidah dan syariah adalah hal yang berbeda. Syariah memberikan makna dan tujuan yang bisa diterima, sehingga proses dan hasil harus baik. Bukan mencampur adukan yang halal dan haram, menjadikan yang haram menjadi halal, dan sebaliknya. Semua tetap berlandaskan pada AlQuran dan Hadist.

\section{Metodologi Penelitian}

Penelitian ini merupakan penelitian dengan metode kualitatif dengan paradigma kritis (Kamayanti, 2016). Untuk mengukur pengungkapan, peneliti melihat laporan-laporan yang menyajikan informasi terkait dalam laporan tahunan. Perbedaan penelitian kali ini adalah pengungkapan tidak hanya diukur di laporan keuangan tetapi juga sosial media bank yang ada, mengingat era digital dimana internet sudah menjadi bagian dari kehidupan 
manusia. Faktanya pengguna internet di Indonesia saat ini sudah mencapai angka 139 juta jiwa (APJII 2016). Dari keseluruhan jumlah penduduk, 59\% nya sudah menggunakan internet banking (sharingvision.com) kemudian peneliti menjabarkannya dengan content analysis baik pengungkapan melalui annual report maupun sosial media. Menurut Krippendorff (2003), Content Analysis merupakan sebuah teknik riset untuk membuat replikasi dan kesimpulan yang valid dari teks-teks yang ada untuk isi yang mereka gunakan.

Sampel yang digunakan adalah perbankan syariah di Indonesia dengan kategori Bank Umum Syariah karena Bank Umum Syariah memiliki laporan tersendiri, sedangkan Unit Usaha Syariah masih ada beberapa laporan perusahaannya yang masih bergabung dengan laporan induknya yaitu bank konvensional. Alasan pemilihan tempat Bank Umum Syariah di Indonesia sesuai dengan lanjutan penelitian Septyan (2018) yang menemukan bahwa pengungkapan bank yang ada di Indonesia memiliki nilai yang paling tinggi dibanding negara lain. Hal ini menunjukkan bahwa bank syariah di Indonesia masih terus berusaha untuk meyakinkan masyarakat untuk mempercayai bahwa bank syariah merupakan lembaga keuangan yang tersedia di negara yang memiliki pemeluk agama Islam terbanyak. Upaya tersebut dilakukan bank syariah dengan melakukan banyak memberikan informasi kegiatan-kegiatan perusahaan melalui annual report.

Paradigma yang diambil dalam penelitian ini adalah kristis seperti yang dilakukan Asutay \& Harningtyas (2015) dan Septyan (2016) dan paradigma spiritualis berdasarkan sumber hukum utama Islam dengan metode/cara/manhaj Salaf (pemahaman orang-orang terdahulu yaitu para sahabat nabi salallahu alaihi wasallam, tabi'in, tabii'ut tabi'in dimana mereka adalah generasi terbaik dalam mempraktekkan dan memahami Islam yang sudah direkomendasikan dalam QS. At. Taubah: 100) untuk dijadikan acuan utama, kemudian didukung penelitipeneliti terdahulu yaitu peneliti melakukan pengumpulan beberapa indeks pengungkapan terkait entitas syariah yang ada di dunia dan merangkumnya menjadi satu.

Setelah melakukan pengembangan indeks pengungkapan, peneliti mencoba mengukur pada beberapa pengungkapan yang ada di bank umum syariah di Indonesia yang laporan tahunannya dapat diakses dan melihat website bank syariah di Indonesia mengingat banyaknya masyarakat sudah menggunakan internet.

\section{HASIL DAN PEMBAHASAN}

Berdasarkan penelitian Septyan (2016) yang telah membuat indeks pengungkapan dari beberapa pengembangan pengungkapan yaitu AAOIFI, Islamic Social Reporting index, dan Islamicity Disclosure Index. Dari ketiga indeks pengungkapan ini peneliti mencoba menyeimbangkannya dengan shariah enterprise theory bahwa entitas syariah harus peduli terhadap seluruh stakeholder baik direct stakeholder yaitu stakeholder yang terlibat langsung dalam menghasilkan laba, maupun indirect stakeholder yang tidak terlibat langsung dalam menghasilkan laba seperti kaum yang membutuhkan, alam dan sebagainya.

Namun jika membahas stakeholder yang tidak secara langsung menghasilkan laba, terdapat indirect stakeholder yang tidak begitu banyak dibahas dalam penelitian-penelitian sebelumnya. Indirect stakeholder ini memiliki kaitan erat dengaan stakeholder. Stakeholder ini adalah keluarga. Dasar pengambilan stakeholder 
ini didasarkan pada maqashid syariah yang memiliki 5 fokus yaitu memelihara akal, jiwa, agama, keturuan dan harta. Penelitian ini berfokus pada bagian hifzun nasb yaitu memelihara keturunan (keluarga). Stakeholder yang disebut keluarga perlu diangkat menjadi perhatian karena memiliki peran penting terhadap kinerja direct stakeholder. Keluarga yang dimaksud mencakup seluruh keluarga personal entitas syariah baik keluarga dari karyawan maupun keluarga dari atasan hingga pemegang saham. Meenakshi et al (2013) menyatakan pentingnya worklife balance antara pekerjaan dengan keluarga. Begitu pula maqashid syariah (tujuan syariah memelihara keturunan (hifzun nasb) dituangkan dengan anjuran untk menikah yang di dalamnya terdapat kewajiban dan hak. Salah satunya kewajiban menjaga keluarga dari api neraka (QS, At Tahrim: 6).

Meier, Kamath, \& He (2010) menyatakan bahwa kecurangan yang ada di lapangan sering disalahkan pada awal terjadinya kecurangan, padahal dilihat jauh kebelakang, kritikan sering ditujukan pada pola pendidikan akuntansi, dan jika ingin melihat jauh kebelakang (Septyan \& Julianto: 2018) menambahkan bahwa kecurangan yang ada dilapangan bisa saja disebabkan oleh keluarga yang bermasalah. Hal ini yang menjadi perhatian penting bahwa keluarga adalaha amanah yang harus diajaga dengan cara meluangkan waktu untuk mendidik dan mengetahui hal yang dibolehkan dan dilarang dalam agama. Kembali lagi pada sifat akuntansi adalah diskursif, maka entitas syariah harus mencerminkan akhlak yang mulia dengan memperhatikan stakeholder lain walaupun tidak berkontribusi terhadap laba entitas itu sendiri.

Mendidik agama juga merupakan kewajiban kepala keluarga sehingga seluruh waktu tidak sepenuhnya digunakan untuk kegiatan di perusahaan seolah perusahaan menjadi keluarga pertama dan tanggung jawab pertama yang menjadikan karyawan tidak menjadi bahan ekploitas tenaga kerja oleh entitas demi memenuhi kebutuhan hasrat entitas tersebut dimana Triyuwono (2012) menyebutkan istilah ekploitasi karyawan dalam hal tenaga dan waktu. Dengan kata lain tidak menjadikan lembur sebagai alasan untuk lebih memiliki pekerjaan. Padahal ada tanggung jawab mendidik anak istri dan kewajiban lainnya terhadap keluarga. Bagi seseorang belum berkeluarga, maka keluarganya adalah orang tua untuk merawat, berbagi waktu dan kewajiban anak lainnya. Maka dalam hal ini peneliti mencoba memberikan indeks pengungkapan untuk indirect stakeholder yang terlupakan yaitu keluarga.

Pada pengembangan indeks ini dibagi menjadi dua fokus utama yaitu keluarga dari direct stakeholder (yang terlibat langsung dengan menghasilkan laba perusahaan), baik keluarga karyawan maupun keluarga atasan dan investor. Seperti pendapat yang menyatakan bahwa laba perusahaan harus nol, karena dalam akuntansi syariah memandang harta bukan segalanya. Tetapi perlu diperhatikan ketika seseorang membuka usaha untuk mengharapkan laba dan pahala dari Tuhannya dalam rangka memenuhi nafkah, maka hal ini menjadi pertimbangan penting sebagian laba didistribusikan kepada keluarga melalui direct stakeholder yaitu investor atau owner. Hal ini tertuang dalam pentingnya dividen yang kemudian akan didistribusikan lagi kepada keluarga.

Direct stakeholder yang perlu diperhatikan lainnya adalah karyawan yang cukup mencurahkan sebagian hidupnya untuk perusahaan. Baik karyawan yang belum menikah maupun yang sudah menikah. Dengan demikian perlu diadakan manajemen waktu yang 
di dalamnya membahas kegiatan pekerjaan yang melebihi jam yang membuat melupakan keluarga atau tidak, lembur dan tunjangan menikah (bagi yang akan menikah) serta beberapa item indeks yang muncul dalam penelitian ini. Termasuk di dalamnya menurut pandangan ulamaulama salaf adalah wanita sebaiknya berada di rumah. Jika wanita sering mendapatkan surat tugas dari atasan, maka sesunggunhnya lebih bergensi wanita yang berada dirumah karena surat tugas yang diberikan langsung dari stakeholder tertinggi yang memiliki alam semesta ini. Surat tugas tersebut tertuang dalam QS. Al-Ahzab: 33. Hameed, Wirman, Alrazi, Nazli, \& Pramono (2003) memberikan item pengungkapan persentasi gender pekerja pria dan wanita di entitas syariah.

Dengan beberapa penjelasan dan landasan di atas, penelitian ini mengembangkan indeks Septyan (2016) dengan indeks pengungkapan sebagai berikut:

Tabel 1. Pengembangan indeks pengungkapan

\begin{tabular}{|l|l|}
\hline \multicolumn{2}{|l|}{ DASAR INFORMASI BANK } \\
\hline 1. & Identitas Bank \\
\hline 2. & Visi bank \\
\hline 3. & Misi Bank \\
\hline
\end{tabular}

\section{ZAKAT DAN KEBIJAKAN SOSIAL}

21. Laporan Zakat

22. Metode Zakat yang digunakan

23. Alasan Penondistribusian Zakat

\section{PELAPORAN KEUANGAN}

4. Laporan Laba Rugi

5. Laporan Posisi Keuangan

6. Laporan Perubahan Ekuitas

7. Laporan Arus Kas

8. Laporan Perubahan Dana Terikat

9. Konsentrassi asset berisiko

10. Sumber investasi tidak terikat

11. Distribusi investasi tidak terikat

12. Komitment dan kontinjensi

13. Pendapatan Halal

14. Pendapatan Non Halal

\section{LAIN-LAIN}

15. Laporan DPS

16. Jumlah Rapat Dewan Direksi

17. Laporan Dewan Direksi

18. Pengungkapan berBahasa Inggris

\section{PELANGGAN}

19. Testimonmi Kepuasan Customer

20. Keluhan dan Tindakan yang diambil

Berdasarkan tabel 1 di atas mengatakan bahwa indeks pada penelitian ini merupakan pengembangan indeks pengungkapan Septyan (2016) pada laporan tahunan bank syariah. Perbedaannya adalah pada indeks ini
24. Laporan Dana Kebajikan

\section{KARYAWAN}

25. Kajian Ilmu Agama untuk karyawan

26. Kebijakan Gaji dan Remunerasi

27. Penghargaan untuk Karyawan

28. Pendidikan dan Pelatihan (PP)

29. Angka Penerimaan PP

\section{ALAM}

30. Target Lingkungan

31. Perlindungan Lingkungan

\section{KELUARGA}

32. Kebijakan Dividen (keluarga investor)

33. Family Gathering

34. Tunjangan Lembur (manager/staff)

35. Batas Jam Lembur (manager/staff)

36. Pernikahan (tunjangan)

37. Persentase gender

38. Cuti

terdapat item kebijakan perusahan namun secara tidak langsung berdampak pada salah satu indirect stakeholder yaitu keluarga, baik keluarga investor, manajer maupun keluarga karyawan. Selain itu, peneliti juga mengambil 
rangkuman dari indeks yang ada pada tabel 1 di atas untuk pengungkapan di sosial media, hanya saja tidak secara spesifik seperti pengungkapan di annual report, sebagai contoh di media sosial cukup memberikan gambaran keuangan secara umum dari laba rugi, laporan posisi keuangan (atau bagiannya yaitu DPK untuk dijadikan item pengungkapan).

Media sosial yang dipilih adalah facebook karena facebook memberikan informasi yang lebih lengkap dalam memposting informasi user dan facebook juga merupakan jejaring soial dengan pengguna terbanyak. Walaupun instagram sekarang sedang booming, namun instagram memiliki keterbatasan pada penyajian informasi. Instagram telah tertanam dipola pikir masyarakat adalah media sosial yang lebih berfokus pada visual gambar dibanding narasi (terlalu banyak narasi bisa membosankan).

Asutay \& Harningtyas (2015) memberikan gambaran dengan Najjar's Model yang menarik terkait dengan hasil pengungkapannya dengan content analysis. Dibawah ini adalah rata-rata hasil pengungkapan di Bank Umum Syariah di Indonesdia dibagi berdasarkan pengkategorian temanya terhadap stakeholder yaitu sebagai berikutt:

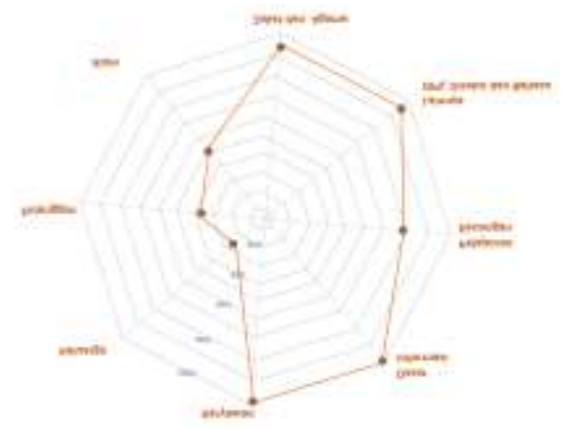

Gambar 1. Rata-rata pengungkapan BUS di Indonesia
Berdasarkan gambar di atas dibuat dengan rancangan yang menggambarkan sebelah kanan adalah direct stakeholder yaitu internal perusahaan yang sangat berkontribusi terhadap perolehan laba. Sedangkan di sebelah kiri adalah indirect stakeholder perusahaan. Hasil di atas menunjukkan ketidakseimbangan bahwa perusahaan patuh terhadap regulasi dunia seperti hal pelaporan keuangan, dasar informasi bank, jajaran direksi/komisaris, pelaporan zakat yang ditujukan untuk mempertahakan dan menigkatkan kredibilitas investor dan owner.

Sedangkan ketertimpangan dengan indirect stakeholder termasuk stakeholder yang baru diperkenalkan dalam penelitian ini memiliki angka yang paling rendah dibanding yang lainnya yaitu dengan rata-rata pengungkapan untuk keluarga sebesar 29\%. Walaupun bisa saja secara internal memiliki kebijakan dalam mensejahterakan indirect stakeholder tidak diungkapkan dalam laproan tahunan, namun dari hasil yang didapat berdasarkan pengungkapan laporan tahunan di atas menunjukan kekurangan kepedulian terhadap indirect stakeholder. Hal ini seperti menggambarkan entitas syariah bekerja mencapai target seperti perusahaan konvesional lainnya.

Dibawah ini disajikan tabel ringkasan dari setiap bank dengan persentase pengungkapan berdasarkan tema seseuai kepedulian terhadap stakeholder. 
Tabel 2. Hasil Persentase Pengungkapan (\%)

\begin{tabular}{|c|l|c|c|c|c|c|c|c|c|c|c|c|c|}
\hline No & Tema Pengungkapan & B1 & B2 & B3 & B4 & B5 & B6 & B7 & B8 & B9 & B10 & B11 & B12 \\
\hline 1 & Dasar Informasi Bank & 100 & 100 & 100 & 100 & 100 & 100 & 100 & 100 & 100 & 100 & 100 & 100 \\
\hline 2 & Pelaporan Keuangan & 82 & 82 & 73 & 82 & 82 & 82 & 82 & 82 & 82 & 82 & 82 & 73 \\
\hline 3 & Lainnya (jajaran direksi) & 75 & 100 & 100 & 100 & 100 & 75 & 100 & 100 & 75 & 100 & 100 & 100 \\
\hline 4 & Zakat (social) & 40 & 40 & 40 & 60 & 60 & 40 & 20 & 40 & 40 & 40 & 40 & 40 \\
\hline 5 & Karyawan & 100 & 100 & 100 & 100 & 100 & 100 & 100 & 100 & 100 & 100 & 100 & 100 \\
\hline 6 & Pelanggan & 50 & 100 & 50 & 50 & 50 & 50 & 0 & 0 & 50 & 0 & 0 & 50 \\
\hline 7 & Alam & 50 & 50 & 50 & 50 & 50 & 50 & 50 & 50 & 50 & 0 & 100 & 50 \\
\hline 8 & Keluarga & 14 & 43 & 14 & 43 & 43 & 14 & 29 & 14 & 29 & 14 & 43 & 43 \\
\hline
\end{tabular}

Keterangan:

B1: Mega Syariah; B2: Bank Muamalah Indoensia; B3: Panin Dubai; B4: BNI Syariah; B5: BRI Syariah; B6 Bank Syariah Mandiri; B7: Bukopin Syariah; B8: Victoria Syariah; B9: BCA Syariah; B10: May Bank; B11: BJB Syariah; B12: Bank Aceh; sampel tahun 2017 dari annual report setiap bank

Pada tabel 2 diatas dihitung banyaknya item yang diungkapkan dari setiap tema tersebut. Sebagai contoh tema Dasar Informasi Bank memiliki 3 item, jika mengungkapkan ketiganya maka memiliki nilai pengungkapan $100 \%$. Ketiga item tersebut yaitu domisili bank bahkan hingga domisili kantor cabang pun disajikan dalam laporan tahunan, visi dan misi bank syariah. Untuk pelaporan keuangan, tidak semua disajikan dalam, kepedulian terhadap karyawan pun pada semua bank umum syariah di Indonesia. Namun, tema pengungkapan lainnya tidak mengungkapkan secara menyeluruh.

Ditemukan beberapa kebijakan yang berbeda pada setiap bank terkait dengan pengungkapan yang dilakukan seperti dalam hal pelaporan keuangan, dimana terdapat item pengungkapan berkonsentrasi pada asset berisiko. Bank Mega Syariah menjalankan four eyes principle sebagai penerapan manajemen risiko pada aktivitas pembiayaan (risiko kredit). Terdapat pemisahan yang tegas pada struktur organisasi, adanya fungsi bisnis dan fungsi kajian risiko (financing reviewer) serta diberlakukannya mekanisme Komite Persetujuan Pembiayaan. Tidak satupun pembiayaan yang dapat disetujui maupun diproses hanya dengan single approval. Lain halnya di BNI Syariah Risiko Kredit:
Metode pengukuran menggunakan Pendekatan Standar (Standardized Approach) mengacu pada ketentuan regulator yang telah menetapkan. Untuk aset keuangan yang diakui di laporan posisi keuangan, eksposur maksimum terhadap risiko kredit sama dengan nilai tercatat.

Pada item pengungkapan lainnya, bank memiliki pendapatan non halal yang didapat dari denda, adanya relasi dengan bank konvensional serta sumber non halal lainnya. Kemudian pednapatan ini disalurkan sesuai dengan standar akuntansi syariah dimana pendapatan non halal disajikan dalam laporan dana kebajikan. Namun berbeda dengan Bank Panin Dubai Syariah, tidak ditemukannya dalam pembukuan pendapatan non halal pada tahun 2017.

Sedangkan jika melihat tema pengungkapan lainnya yaitu jajaran rapat direksi beberapa mencapai $12 \mathrm{kali}$ pertemuan sesuai aturan Bank Indonesia, namun pada prakteknya tidak seluruhnya mencapai angka tersebut. Hal ini dimungkinkan sistem syariah di Indonesia ketika memiliki produk baru di salah satu bank, maka dibuatkan fatwa dimana dimana fatwa tersebut dapat diguankan untuk bank lainnya. Berbeda dengan bank syariah di timur tengah. Maka dalam beberapa penelitian karakteristik Dewan Pengawas Syariah 
salah satunya diukur dengan banyaknya pengalaman di beberapa entitas karena pengetahuan akan tiap produk di bank berbeda. Sedangkan di Indonesia, fatwa untuk setiap produk bukan fatwa untuk satu entitas yang mencetuskan produk tersebut, tetapi fatwa tersebut dapat digunakan untuk entitas lainnya. Dalam hal pelaporan Bahasa inggris, BNI Syariah dan Victoria syariah hanya menggunakan pada bagian laporan keuangannya, sedangkan bank syariah lainnya menggunakan Bahasa inggris pada setiap pengungkapan di laporan tahunan.

Dalam hal zakat, seluruhnya membuat laporan tentang zakat namun tidak secara spesifik penjelasan penyalurannya, hal ini dikarenakan bank adalah enttias yang tidak bergerak dalam bidang pengelolaan dana zakat seperti yang disebutkan dalam PSAK 109. Semua bank menyalurkan zakatnya pada Lembaga Amil Zakat bahkan beberapa bank memiliki anak perusahaan yang bergerak sebagai Lembaga Amil zakat seperti Bank Syariah Mandiri. Sedangkan untuk penghimpunannya, berdasarkan PSAK Syariah No. 101 diperoleh dari bank syariah itu sendiri atau pun dari pihak lain. Dengan kata lain bank syariah wajib membayar zakat. Berdasarkan aturan AAOIFI bahwa zakat perusahaan dibayarkan berdasarkan net asset ataupun nilai investasi bersih. Dua metode ini tidak digunakan dalam bank syariah di Indonesia karena belum tentu patuh pada standar akuntansi yang diterbitkan AAOIFI. Seperti yang diutarakan oleh Septyan (2016) menunjukkan hasil bahwa bank syariah di Bahrain dan Inggris menggunakan standar zakat AAOIFI karena dilihat dari sturktur organisasi (termasuk DPS bank syariah di Inggris) merupakan anggota AOAIFI. Di Indonesia metode zakat yang digunakan adalah $2.5 \%$ dari laba bersih, dan itu pun hanya diungkapkan oleh BNI syariah dan BRI Syariah. Sedangkan Bank
Muamalah hanya menjelaskan pembayaran zakat bank di ambil dari cadangan biaya yang telah dibentuk pada tahun 2015.

Melihat kepedulian lainnya yaitu terhadap pelanggan dimana titik puncak dari pelayanan adalah kepuasan pelanggan. Bank Muamalat memperlihatkan angka kepuasan nasabah $77.03 \%$ namun tidak ada testimoni secara detail dari setiap bank dalam annual reportnya. Begitu juga dngan BNI syariah hanya mengungkapkan program Survei Kepuasana Nasabah saja. Tidak pada laporannya tahun 2014 mencantumkan testinomi beberapa nasabah. Dalam hal penanganan keluhan nasabah bun sedkit yang mengungkapkan angka seperti Bank Aceh, Panin Dubai dan Bank Mega Syariah karena mereka telah menindaklanjuti dan menyelesaikan seluruh keluhannya yang diadukan kepadanya. Sedangkan di BRI syaiah dibuat nasabah gathering untuk meningkatkan kepuasan nasabah.

Kemudian pengungkapan indirect stakeholder yaitu stakeholder keluarga yang menjadi bahasan utama pada penelitin ini. Salah satu item adalah family gathering. Peneliti memasukan item ini adalah untuk menjembatani pilihan antara keluarga dengan pekerjaan, maka dibutuhkan family gathering sebagai solusi menghabiskan disaat pilihan menghabiskan waktu untuk perusahaan atau keluarga, setidaknya memliki sebagian kecil dari waktu untuk keduanya. Sayangnya kegiatan ini tidak diungkapkan dalam laporan tahunan. Mungkin saja tidak ada kebijakan perusahaan mengatur hal tersebut, namun dapat dilakukan individu secara sukarela mengadakan kegaitan tersebut. Pada Bank Mega Syariah hanya ada employee gathering dan BRI Syariah hanya ada nasabah gathering. 
Begitu pun beratnya lembur dan batas jam tidak menunjukan berbagi kesejahteraan entitas syariah kepada keluarga, tidak seluruh waktu dihabiskan untk perusahaan sehingga mengabaikan keluarga, yang dibutuhkan bukan hanya uang, kecuali keluarga yang mensyaratkan hal tersbut, berarti keluarganya telah terkena jerat-jerat kapitalis dan materealistis karena semua yang dibutuhkan adalah uang, ada hak atas setiap orang dari diri manusia ini. Seperti kisah Abu Darda radhiallahu anhu yang terlalu sibuk beribadah hingga melupakan istrinya, hal ini tidak diperbolehkan. Padahal notabenenya adalah ibadah, ibadah saja memiliki porsi yang berlebihan tetapi juga tidak kurang, apalagi urusan dunia dan pekerjaan hingga melalaikan hak atas diri dan keluarga.

Sedangkan untuk jumlah gender pekerja, beberapa pendapat menyatakan bahwa memang laki-laki memiliki kewajiban dalam menjalankan tugasnya mencari nafkah. Item ini muncul tidak pertama kalinya muncul pada penelitian ini tetapi juga pada penelitian Hameed, Wirman, Alrazi, Nazli, \& Pramono (2003). Dalam penelitian Meier, Kamath, \& He (2010) mengatakan bahwa pada saat terjadi kecurangan di tempat kerja bukan pada terjadi pada awal kasus kecurangan itu, tetapi jauh dari itu semua yaitu ditarik pada pola pendidikan akuntansinya yang harus pentuh etika. Namun hal itu bisa saja peneliti tarik jauh kebelakang bahwa yang harus dikoreksi bukan pada pola pendidikana (itu hanya awal), tetapi yang harus dikoreksi adalah pola pendidikan dirumah sebagai fondasi terkuat membangun karakter setiap manusia. Pendidikan di perguruan tinggi hanya pendukung. Dalam QS. Al-Ahzab ayat 33 menyatakan juga bahwa sebaiknya wanita berada di rumah (tidak bekerja diluar dengan kondisi tertentu). Sehingga hal ini menjadi cukup urgen bahwa gender berpengaruh terhadap keberlanjtuan perusahaan. Jika dalam mempertahankan perusahaan mampu, tetapi mengabaikan keluarga, maka secara personal indivdiu di bank syariah ada yang perlu dibenahi tertama dalam mencatetapi tujuan syariah yaitu maqashid syariah.

Keseimbangan ini diatur dalam maqashid syariah yang memiliki beberapa konsentrasi. Hanya saja stakeholder keluarga dalam ranah akuntansi ini hampir terlupakan maka muncul berbagai penelitian seperti worklife balance dan sejenisnya dalam disiplin ilmu yang berbeda. Penelitian ini pun terinspirasi dari pengalaman peneliti dan peneliti terdahulu serta regulasi Tuhan dalam memeperhatikan seluruh stakeholder.

\section{KESIMPULAN DAN IMPLIKASI}

Penelitian ini memunculkan stakeholder tambahan yaitu indirect stakeholder yang memiliki kaitan penting dengan direct stakeholder karena keberhasilan perusahaan syariah tidak hanya dilihat dari entitas syariah itu bertumbuh, laba meningkat, asset bertambah dan sejenisnya, tetapi entitas syariah dikatakn berhasil jika mampu berbagi kesejahteraan dengan sekitarnya dengan cara memperhatikan seluruh stakeholder.

Beberpa item pengungkapan ditambahkan dalam penelitian ini terkait indirect stakeholder tersebut. Sayangnya hasil rata-rata pengungkapan menunjukkan kepedulian entitas terhadap stakeholder yang terlibat langsung dalam menghasilkan laba. Stakeholder lainnya seperti alam, pelanggan, bahkan keluarga masih memiliki nilai yang sangat sendikit. Dengan beberapa temuan lainnya yang mencoba mendeskripsikan lebih banyak hal-hal menarik yang diungkapkan dari setiap bank syariah. 


\section{DAFTAR PUSTAKA}

Asutay, M., \& Harningtyas, A. F. (2015). Developing Maqasid al - Shari'ah Index to Evaluate Social Performance of Islamic Banks: A Conceptual and Empirical . International Journal of Islamic Economics and Finance Studies, Vol 1 (1).

Docekalova, M. (2013). Construction of Corporate Social Performance Indicators for Czech Manufacturing Industry. Acta Universitas Agriculturae et Silviculturae Mendeliane Brunensis, 309-315.

Hameed, S., Wirman, A., Alrazi, B., Nazli, M., \& Pramono, S. (2003). alternative Disclosure \& Performance Measures for Islamic Banks. International Conference on Information System and Islam (hal. 1-34). Kuala Lumpur: IIUM.

Haniffa , R., \& Hudaib, M. (2007). Exploring the Ethical Identity of Islamic Banks via Communication in Annual Report. Journal of Business Ethics, 97-116.

Haniffa, R. (2002). Social Reporting Disclosure: An Islamic Perspective. Indonesian Management and Accounting Research, Vol 1 (2), 128146.

Harahap, S. S. (2002). The Disclosure of Islamic Value - annual Report The Analysis of Bank Muamalat Indonesia's Annual Report. Iqtishad.

Kamayanti, A. (2016). Metodologi Pnelitian Kualitatif Akuntansi (Pengantar Religiositas Keilmuan. Jakarta: Rumah Peneleh.
Krippendorff, K. (2003). Content Analysis: An Introduction to Its Methodhology 2nd Edition. London: SAGE Publications.

Meenakshi, S. P., Subramanyam, V., \& Ravichandran, K. (2013). The Importance of Work-Life-Balance. IOSR Journal of Business and Management (IOSR-JBM) vol 14 (3), 31-35.

Meier, H. H., Kamath, R. R., \& He, Y. (2010). Course on Forensic and Fraud Examination in the Accounting Curriculum. Journal of Leadership, Accountability and Ethics, Vol 8 (1), 25-33.

Mulawarman, A. D. (2006). Pensucian Pendidikan Akuntansi. Prosiding Konferensi Merefleksi Domain Pendidikan Ekonomi dan Bisnis. Salatiga: Universitas Kristen Satya Wacana.

Septyan, K. (2016). Reformulasi Indeks Pengungkapan Entitas Syariah dan Keunikan Bergaam Kebijakan Nilai Syariah di Beberapa Negara. Jurnal Equity, Vol 19 (2), 83-98.

Septyan, K. (2018). Determinasi Tingkat Pengungkapan Bank Syariah di Beberapa Negara. Jurnal Akuntansi dan Keuangan Islam, Vol. 6 (2), 127 141.

Septyan, K., \& Julianto, W. (2018). Model Pembelajaran Syariah di Jurusan Akuntansi. Jurnal Pendidikan Ekonomi dan Bsinis (JPEB), Vol. 6 (1), 15-24.

Triyuwono, I. (2012). Perspektif, Metodologi dan Teori Akuntansi Syariah, Edisi Dua. Jakarta: Rajawali Pers 